\title{
The Sources of Inequality in Bolivia
}

\author{
Jonathan M. Fortun Vargas
}

\begin{abstract}
Latin America has often been depicted as one of the most unequal regions in the world. However, after the rising of inequality, the figure declines dramatically starting from the year 2000. In this setting, Bolivia has been one of the poorest performers on income distribution efforts, lately, this situation has been improving. The author investigates the dynamics of this change through an analysis of household level surveys for 4 different years $(2003 / 04,2005,2008$ and 2009). The research applies a method of inequality decomposition - as developed by G.S. Fields in 2003; this technique consists on regressing the expenditure of households against a vector of explanatory variables. The results suggest that education (more than other variables) has contributed on the reduction of inequality in Bolivia. Moreover, the sources of inequality are mainly attributed to the differences on human capital accumulation more than any other variables, such as the gender of the household head or the ethnical origin of the household. The results are in line with similar work made by other authors on the same issue.
\end{abstract}

Index Terms-Bolivia, Economic Development, Income Distribution, Inequality.

\section{INTRODUCTION}

The present paper will assess the dynamics of change in Bolivia through the utilization of household level surveys and inequality decomposition techniques developed by Fields in 2003 [1]. This research follows the previous research of other authors such as Gray Molina and Yañez [2]-[3].

Section I will deal with a broad view of the history of inequality in Latin America and Bolivia, and it explores the reasons of why inequality has been reduced in recent times. Section II deals with the description to be utilized, Section III will explore the econometric technique utilized; the results of the study are presented in section IV and finally Section V will address the conclusions and potential policy implications of the findings presented.

Latin America is often depicted as the most unequal region in the world. The inequality statistics for the region are surprising: Latin American Countries present a Gini coefficient of 0.53 in the mid-2000s, which is 18 percent more unequal than Sub-Saharan Africa, 36 percent more unequal than East Asia and the Pacific and 65 percent more unequal than high income countries (Figure 1).

Income inequality in Latin American increased substantially during the so called "lost decade of the $80 \mathrm{~s}$ " and the consequent period of structural reforms during the decade

Manuscript received July 25, 2012; revised August 30, 2012.

Jonathan M. Fortun Vargas is with Graduate School of International Cooperation Studies, Kobe University, Japan (e-mail: fortun@stu.kobe-u.ac.jp) of the 90s. The evidence (e.g. [4]-[8]) suggests that the effects of the debt crisis during the 1980s -along with the periods of hyperinflation in the region- were un-equalizing. The path of transmission is explained by López Calva \& Lustig [9]: "the poor were less able to protect themselves from high and runaway inflation and orthodox adjustment programs frequently resulted in overkill, those in the poor and the middle-income wages were hurt disproportionately while the income share of the top $10 \%$ rose"

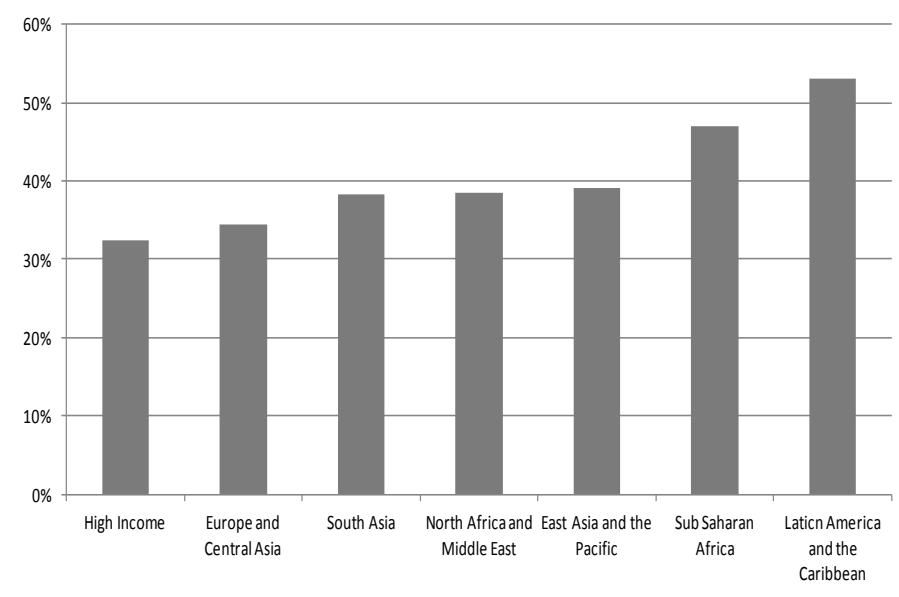

Fig. 1. Gini coefficients by region, 2004. Source: own calculation based on [10]

Lustig and Taylor, in 1994, elaborate further on the adjustment overkill, stating that the reduction of fiscal deficits went beyond what was necessary to restore equilibrium in the external accounts and that over-adjustment had counterproductive effects on stabilization itself [11].

Moreover, as Janvry \& Sadoulet explain, "the un-equalizing effect of the crisis was compounded because safety nets for the poor and vulnerable were conspicuously absent (or poorly designed and inadequate) in the Washington led structural adjustment programs in the 1980s and some part of the 1990s" [12].

However, after the rising of inequality, the figure decline dramatically from 2000 . Out of the seventeen countries on which data is available, twelve experienced a decline in their Gini coefficients, (Figure 2). The average decline for the twelve countries was 6 percent (for the period 2001 to 2009).

The interesting fact about this new movement towards equality in Latin America is that the effect was widespread. Inequality declined in high inequality countries (such as Brazil and Bolivia), countries with traditional low inequality (for LAC standards) such as Argentina. The indices of inequality declined for fast growing countries (Chile and Peru), but also on growing giants (Brazil and Mexico), countries recently hit by crises (Argentina), or countries with relatively stable macroeconomic figures (Peru, Chile and 
Panama).

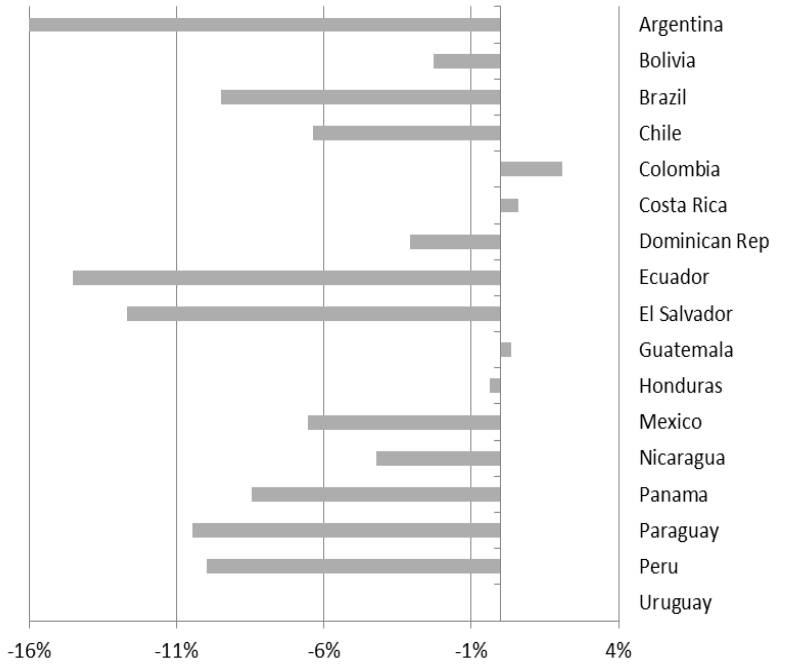

Fig. 2. Percent change in Gini coefficients by country, 2001-2009* Source: Own calculation based on information of Socio-Economic Database for Latin America and the Caribbean (CEDLAS and The World Bank). Note: Information for Bolivia and Colombia is for the years 2001 to 2007, information for Ecuador is for the years 2000 to 2007, information for El Salvador is for the years 2001 to 2008, information for Guatemala is for the years 2000 to 2006, information for Nicaragua is for the years 2001 to 2005, information for Uruguay is for the years 2000 to 2006, information for Venezuela was unavailable, data discrepancy given data availability

Traditionally, inequality in Latin America is attributed to the result of the state capture by elites [13], capital market imperfections [14], inequality of opportunity, lack of good education [12], labor market segmentation [15] and discrimination against women and indigenous groups [4], as stated by several authors. Therefore from any perspective the fall in inequality is good news.

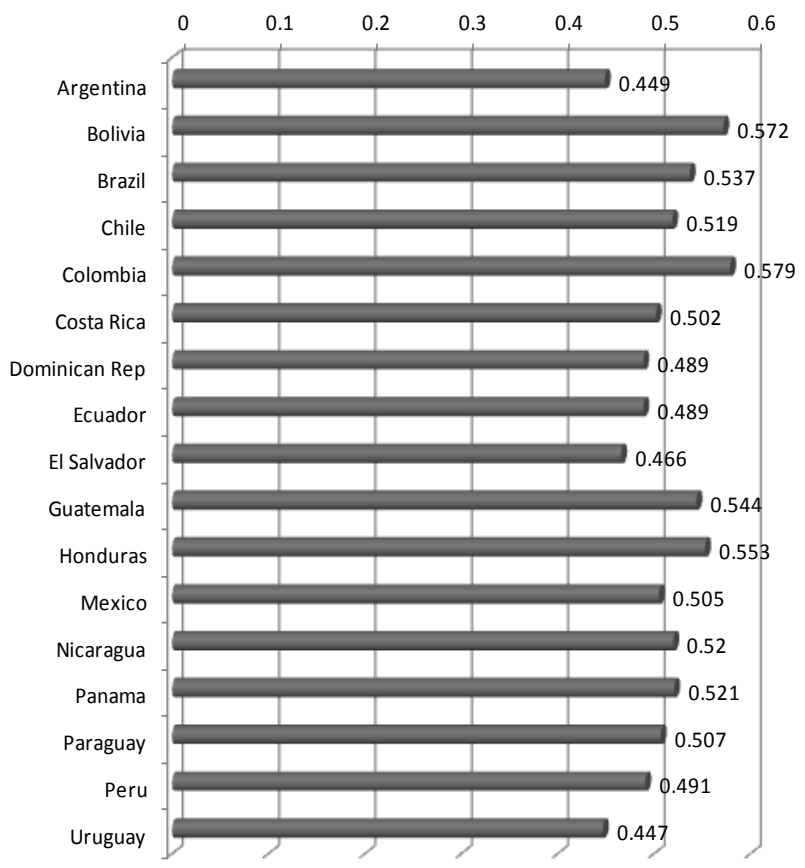

Fig. 3. Gini coefficients for selected LAC countries 2009*. Source: Own calculation based on information of Socio-Economic Database for Latin America and the Caribbean (CEDLAS and The World Bank). Note: Information for Bolivia, Colombia and Ecuador is for the year 2007 information for El Salvador is for the year 2008, information for Guatemala and Uruguay is for the year 2006, information for Nicaragua is for the year 2005, information for Venezuela was unavailable
Given these circumstances, it is imperative to ask how and why this decline occurred. A proper understanding of the causes that contributed to the reduction of the inequality in Latin American countries in the past decades, will allow policymakers to i) improve the levels of equality in the region, ii) maintain a proper path to equality and iii) design future policies that could actually take the process of equalization even further.

\section{A. Declining Inequality}

The last recent years, Latin American countries have seen an important expansion in its macroeconomic variables, most of them began to benefit from very favorable terms of trade -including the recent increase in commodity prices- (Figure 4).

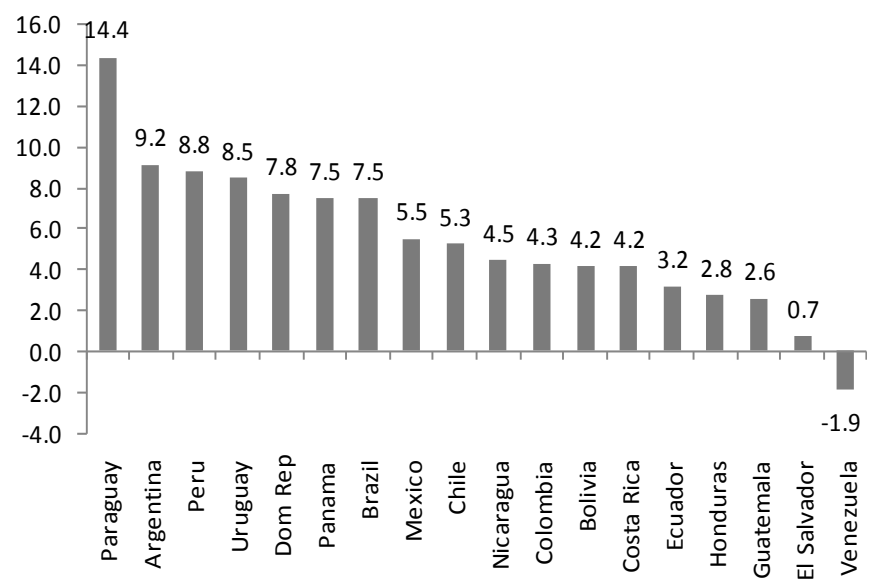

Fig. 4. Real GDP growth rates between 2009 and 2010 for selected LAC countries. Source: Own calculation based on IMF's statistics for 2009 and 2010

Two leading factors seem to account for the decline in inequality across the region: a decrease in the earnings gap between skilled and low skilled workers and an increase in government transfers to the poor. The decrease in the earnings gap, seems to be mainly the result of the expansion of basic education during the last couple of decades; it might also be a consequence of the petering out of the once un-equalizing effects of skill biased technical change in the 1990 s associated with the opening up of trade and investment [9].

The equalizing contribution of government transfers seems to be associated with the implementation or expansion of large scale conditional cash transfer programs. In the following work, I will investigate on the causes of the reduction in inequality in Bolivia through the application of a regression based decomposition, as developed by [1].

\section{B. Bolivia}

Bolivia has traditionally been one of the weakest performers on both economic growth and poverty reduction in Latin America. The low economic growth rate is typical of a natural resource based economy; a diverse range of authors, (e.g. [16]-[20]) argue about the different reasons of the slow growth in Bolivia, they present several reason which go from institutional and productivity obstacles to effects derived 
from the fact that Bolivia is a landlocked country.

TABLE I: GDP EVOLUTION (BOLIVIA)

\begin{tabular}{crr} 
Bolivia & $\begin{array}{c}\text { GDPoonstant } \\
\text { million 2000US\$ }\end{array}$ & Gowth Rate \\
\hline $\mathbf{2 0 0 0}$ & $8,397.86$ & NA \\
\hline $\mathbf{2 0 0 1}$ & $8,539.26$ & $1.68 \%$ \\
\hline $\mathbf{2 0 0 2}$ & $8,751.51$ & $2.49 \%$ \\
\hline $\mathbf{2 0 0 3}$ & $8,988.79$ & $2.71 \%$ \\
\hline $\mathbf{2 0 0 4}$ & $9,363.92$ & $4.17 \%$ \\
\hline $\mathbf{2 0 0 5}$ & $9,777.94$ & $4.42 \%$ \\
\hline $\mathbf{2 0 0 6}$ & $10,246.99$ & $4.80 \%$ \\
\hline $\mathbf{2 0 0 7}$ & $10,714.70$ & $4.56 \%$ \\
\hline $\mathbf{2 0 0 8}$ & $11,373.50$ & $6.15 \%$ \\
\hline $\mathbf{2 0 0 9}$ & $11,755.30$ & $3.36 \%$ \\
\hline $\mathbf{2 0 1 0}$ & $12,240.41$ & $4.13 \%$ \\
\hline & Growth Avg & $\mathbf{3 . 8 5 \%}$
\end{tabular}

Source: Own calculation based on IMF's International Financial Statistics, January 2012

TABLE II: AVERAGE GDP GROWTH RATE 2000-2010 FOR SELECTED LAC COUNTRIES

\begin{tabular}{l|cl|c}
\multicolumn{1}{c}{ Country } & Avg GrouthRate & \multicolumn{1}{c}{ Country } & Avg GouthRate \\
\hline Argentina & $4.6 \%$ & Guatemala & $3.3 \%$ \\
Bolivia & $3.8 \%$ & Honduras & $4.1 \%$ \\
Brazil & $3.6 \%$ & Mexico & $1.8 \%$ \\
Chile & $3.7 \%$ & Nicaragua & $3.4 \%$ \\
Colombia & $4.1 \%$ & Panama & $6.0 \%$ \\
CostaRica & $4.3 \%$ & Paraguay & $4.1 \%$ \\
DominicanRep & $5.4 \%$ & Peru & $5.7 \%$ \\
Eauador & $4.6 \%$ & Uruguay & $3.3 \%$ \\
ESalvador & $1.9 \%$ & Avg & $\mathbf{4 0 \%}$
\end{tabular}

Source: Own calculation based on IMF's International Financial Statistics, January 2012

However, there has been very little research regarding the determinants of inequality in Bolivia. This is a surprising factor since this country has presented through the years some of the highest Gini coefficients in the region. This then, becomes an important field given the consequences of inequality presented in standard literature. Urquiola argues that high levels of inequality impact on growth, also, disparities in education and labor markets for women, indigenous peoples and rural population have diminished the capacity to build cumulative capital in Bolivia [21]. Some authors, (e.g. [2], [22]) suggest that despite the fact that Bolivia has been one of the most active reformers in education, health and decentralization; the cumulative impact of these policies is not seen in the improvement of development indicators.

\section{Poverty and Inequality in Bolivia}

Bolivia has had a below average overall level of growth in the last decade, when compared to other Latin American countries, averaging an annual GDP growth rate of $3.8 \%$ (see Table 1 and Table 2). Per capita growth had an average of $2 \%$ which is also below average than the peer group (See Table 3 and Table 4). On both counts, Bolivia is lagged in the region.
TABLE III: GDP PER CAPITA EVOLUTION (BOLIVIA)

\begin{tabular}{crc} 
Bolivia & $\begin{array}{c}\text { ODPpercapita } \\
\text { 2000US\$ }\end{array}$ & GowthRte \\
\hline $\mathbf{2 0 0 0}$ & $1,010.91$ & \multicolumn{1}{c}{ NA } \\
\hline $\mathbf{2 0 0 1}$ & $1,007.38$ & $-0.35 \%$ \\
\hline $\mathbf{2 0 0 2}$ & $1,012.13$ & $0.47 \%$ \\
\hline $\mathbf{2 0 0 3}$ & $1,019.61$ & $0.74 \%$ \\
\hline $\mathbf{2 0 0 4}$ & $1,042.41$ & $2.24 \%$ \\
\hline $\mathbf{2 0 0 5}$ & $1,069.02$ & $2.55 \%$ \\
\hline $\mathbf{2 0 0 6}$ & $1,101.04$ & $3.00 \%$ \\
\hline $\mathbf{2 0 0 7}$ & $1,132.21$ & $2.83 \%$ \\
\hline $\mathbf{2 0 0 8}$ & $1,182.46$ & $4.44 \%$ \\
\hline $\mathbf{2 0 0 9}$ & $1,202.78$ & $1.72 \%$ \\
\hline $\mathbf{2 0 1 0}$ & $1,232.69$ & $2.49 \%$ \\
\hline & Growth Avg & $\mathbf{2 0 1 \%}$
\end{tabular}

Source: Own calculation based on IMF's International Financial Statistics, January 2012

TABLE IV: AVERAGE GDP PER CAPITA GROWTH RATE 2000-2010 FOR SELECTED LAC COUNTRIES

\begin{tabular}{l|cl|c}
\multicolumn{1}{c}{ Country } & Avg GouthRate & \multicolumn{1}{c}{ Country } & Avg GrowthRate \\
\hline Argentina & $3.6 \%$ & Guatemala & $0.8 \%$ \\
Bolivia & $20 \%$ & Honduras & $20 \%$ \\
Brazil & $25 \%$ & Mexico & $0.5 \%$ \\
Chile & $27 \%$ & Nicaragua & $21 \%$ \\
Colombia & $25 \%$ & Panama & $4.2 \%$ \\
CostaRica & $25 \%$ & Paraguay & $22 \%$ \\
Dominican Rep & $3.8 \%$ & Peru & $4.5 \%$ \\
Earador & $3.0 \%$ & Uruguay & $3.1 \%$ \\
ESalvador & $1.5 \%$ & Avg & $\mathbf{2 6 \%}$
\end{tabular}

Source: Own calculation based on IMF's International Financial Statistics, January 2012

The important issue; however is that the poverty level has experienced a decrease since 2007. Most of the decline in poverty figures could be traced to decline in urban poverty and an important decline in rural poverty between 2008 and 2009. Moreover, extreme poverty, proxied by indigence measures, has declined over the period (see Table 5).

It is argued by policymakers in Bolivia, that the reduction of poverty is attributed to the implementation of programs of Cash Conditional Transfers (CCTs) and other pro-poor growth policies inducted by the recent government. However a formal research presenting empirical evidence of these claims has not been presented to date.

The existent work regarding pro poor growth in Bolivia has been mainly concentrated in the relatively low growth/poverty reduction sensitivity, and the long lasting nature of income and non-income inequality. For example Klasen et al. in 2004, show that while economic growth has been pro poor in the early 90s it was not fast enough to lead to significant poverty reduction. They also investigate about the causes of poverty reduction in Bolivia, they state that close to two thirds of poverty reduction was due to growth effects rather than distributional effects; moreover they explain that urban economic growth tended to be relatively anti-poor [23].

Klasen et al. use a CGE model to estimate potential scenarios for future poverty reduction. They find that positive shocks attributed to an increased national rent -due to exports of natural resources, for example- are likely to boost growth 
and reduced urban poverty. However, they also argue that this effect would lead to rising inequality and rising rural poverty [23]. Their findings go in line with other research on growth and pro poor growth in Bolivia, ([2], [24], [25]).

TABLE V: SELECTED POVERTY AND INEQUALITY INDICATORS 1996-2009 (BOLIVIA)

\begin{tabular}{|c|c|c|c|c|c|c|c|}
\hline \multirow{2}{*}{ Year } & \multicolumn{3}{|c|}{ Poverty } & \multicolumn{3}{|c|}{ Indigence } & \multirow{2}{*}{ Gini } \\
\hline & HD & Hl & H2 & H) & HI & H2 & \\
\hline \multicolumn{8}{|l|}{ Country } \\
\hline 1996 & 64.79 & 36.67 & 25.96 & 41.19 & 22.49 & 15.76 & 0.5935 \\
\hline 1997 & 63.59 & 33.73 & 22.73 & 38.08 & 18.93 & 1251 & 0.5852 \\
\hline 1999 & 63.47 & 35.99 & 25.62 & 40.74 & 2222 & 15.86 & 0.5755 \\
\hline 2000 & 66.38 & 40.16 & 29.81 & 45.16 & 26.32 & 19.53 & 0.6177 \\
\hline 2001 & 63.12 & 34.55 & 23.88 & 38.84 & 20.06 & 13.89 & 0.5916 \\
\hline 2002 & 63.33 & 34.88 & 24.24 & 39.54 & 20.57 & 14.37 & 0.5978 \\
\hline $2003-2004$ & 63.15 & 31.11 & 19.79 & 34.50 & 15.92 & 9.88 & \\
\hline 2005 & 60.59 & 34.13 & 23.80 & 38.16 & 20.30 & 14.08 & 0.6000 \\
\hline 2006 & 59.92 & 32.39 & 21.79 & 37.68 & 18.15 & 11.87 & 0.5900 \\
\hline 2007 & 60.10 & 30.52 & 20.11 & 37.70 & 16.26 & 10.39 & 0.5644 \\
\hline 2008 & 57.33 & 27.81 & 17.90 & 30.14 & 14.26 & 9.26 & 0.5161 \\
\hline 2009 & 51.31 & 24.60 & 15.91 & 26.06 & 1272 & 8.58 & 0.5019 \\
\hline \multicolumn{8}{|l|}{ Unban } \\
\hline 1996 & 51.91 & 22.14 & 12.32 & 23.72 & 7.94 & 3.96 & 0.5145 \\
\hline 1997 & 54.47 & 23.83 & 13.66 & 24.88 & 9.16 & 4.79 & 0.5249 \\
\hline 1999 & 51.36 & 22.19 & 1275 & 23.51 & 8.71 & 4.85 & 0.4864 \\
\hline 2000 & 54.47 & 25.60 & 15.49 & 27.93 & 10.97 & 6.19 & 0.5262 \\
\hline 2001 & 54.28 & 24.60 & 14.65 & 26.18 & 10.16 & 5.94 & 0.5340 \\
\hline 2002 & 53.91 & 23.81 & 13.76 & 25.71 & 9.43 & 5.15 & 0.5390 \\
\hline $2003-2004$ & 54.41 & 22.20 & 11.97 & 22.95 & 7.64 & 3.76 & \\
\hline 2005 & 51.05 & 22.84 & 13.05 & 24.30 & 8.68 & 4.67 & 0.5400 \\
\hline 2006 & 50.27 & 21.80 & 12.21 & 23.36 & 7.94 & 4.09 & 0.5300 \\
\hline 2007 & 50.90 & 21.23 & 11.66 & 23.67 & 7.46 & 3.37 & 0.5067 \\
\hline 2008 & 48.72 & 19.64 & 10.77 & 18.89 & 6.77 & 3.63 & 0.4637 \\
\hline 2009 & 43.55 & 17.03 & 9.23 & 16.09 & 5.65 & 3.20 & 0.4507 \\
\hline \multicolumn{8}{|l|}{ Rural } \\
\hline 1996 & 84.43 & 58.82 & 46.75 & 67.82 & 44.67 & 33.76 & 0.6143 \\
\hline 1997 & 78.01 & 49.40 & 37.07 & 58.96 & 34.39 & 24.73 & 0.6252 \\
\hline 1999 & 84.00 & 59.37 & 47.43 & 69.94 & 45.12 & 34.50 & 0.6363 \\
\hline 2000 & 87.02 & 65.39 & 54.62 & 75.01 & 52.92 & 42.65 & 0.6896 \\
\hline 2001 & 77.69 & 50.95 & 39.10 & 59.71 & 36.39 & 27.00 & 0.6353 \\
\hline 2002 & 78.80 & 53.08 & 41.44 & 62.27 & 38.89 & 29.53 & 0.6258 \\
\hline $2003-2004$ & 77.67 & 45.94 & 32.79 & 53.72 & 29.70 & 20.03 & n.d. \\
\hline 2005 & 77.60 & 54.29 & 42.97 & 62.90 & 41.03 & 30.86 & 0.6600 \\
\hline 2006 & 76.47 & 50.55 & 38.22 & 62.25 & 35.67 & 25.23 & 0.6400 \\
\hline 2007 & 77.29 & 47.90 & 35.92 & 63.94 & 3273 & 23.54 & 0.6355 \\
\hline 2008 & 73.64 & 43.31 & 31.41 & 51.47 & 28.45 & 19.93 & 0.5551 \\
\hline 2009 & 66.43 & 39.34 & 28.94 & 45.48 & 26.50 & 19.04 & 0.5337 \\
\hline
\end{tabular}

Source: Adapted from Bolivia's Analysis Unit for Social and Economical Policies [26]. Note: The Poverty lines for each year are calculated based on a Calories Consumption Method. The Poverty and Indigence Lines for each year are displayed in Table 7 and Table 8 in the Appendix

With the exception of recent research conducted by Gray Molina \& Yañez [3], empirical research that explains the reasons behind the declining inequality in Bolivia is not provided. Therefore an analysis to decompose the elements of inequality in Bolivia would add important information for policymakers, scholars and practitioners in general. Moreover the suspected contribution of recent CCT programs to the reduction of poverty and inequality needs special attention.

\section{Social Transfers in Bolivia's Recent History}

Recent policies related to conditional cash transfers have been very popular in recent times in Bolivia. Additional revenues from the hydrocarbons sector currently provide funding for at least two social transfer programs. The first program is called Juancito Pinto, which supports schooling age children. The second program is called Renta Dignidad which aims at the elderly. Both programs account for over US\$ 230 million or approximately $2 \%$ of the GDP.

According to official data for 2011 (for the figures of the program Renta Dignidad data is retrieved from Bolivia's National Social Security Regulator, for the case of the program Juancito Pinto the figures come from Bolivia's Ministry of Education.), transfers reach over 1.6 million children and approximately 891.000 men and women over 60 years old. While the first program is modeled over the Bono Escuela program for the city of El Alto in Bolivia, it maintains lots of similarities with other programs in the Region (Bolsa Familia in Brazil, Progresa in Mexico, to cite some). On the other hand, the second program Renta Dignidad is an expansion of the Bonosol program, which was financed with the revenue of privatized ${ }^{1}$ companies in Bolivia; the difference between Bonosol and the current program is the source of funding: for nine consecutive years the Bonosol program was financed through a combination of collected revenue from privatized companies and internal debt, from 2008 the new program Renta Dignidad is financed through hydrocarbons taxes and royalty payments to the regions product of the nationalization of the hydrocarbons industry.

The Juancito Pinto transfer was created in 2006 establishing an annual cash grant of around US\$ 30 for each child from first to sixth grade in public elementary schools, in July 2008 the program was expanded to benefit children up to 8th grade of elementary public schools.

The current program Renta Dignidad was formally introduced in 2008, while the original program dates back to 1996. In its present form, the program is granted to all elderly citizens (over 60 years old); the amount of the grant varies from US\$ 260 to US\$ 345 depending on the social security payments of the beneficiaries.

To date, there are no specific studies that analyze the impact of these recent programs regarding poverty and inequality. However Jemio, 2006 presents a study regarding the Bonosol program. Using Household survey data for the years 2001, 2002 and 2003/4, Jemio finds two important welfare effects related to this specific program. First, cash transfers to the elderly, while universal, have a stronger incidence among the poorest decile of the population. In the bottom three deciles close to $15 \%$ of households receive the payment. In the top three deciles the figure drops to around $10 \%$. Close to $20 \%$ of rural households receive the benefit in the 3 poorest deciles. The second important finding is that, while mostly concentrated on the poor, the poverty-reducing effect is relatively small for 2001 and 2002; however the

1 In the period of 1993 to 1997 the government of then president Gonzalo Sanchez de Lozada applied a policy called capitalization, where numerous public sector enterprises were privatized in a specific scheme: Investors acquired a 50\% share and management of the enterprises, while the Bolivian government kept the remaining $50 \%$ share. 
impact for the 2003/4 period is stronger [27].

\section{DATA DESCRIPTION}

The data utilized for the analysis will be based on Household surveys compiled by Bolivia's National Statistical Institute (INE) and Bolivia's Analysis Unit for Social, Economical and Political Policies (UDAPE). The Household Surveys utilized are the ones for the years 2003-4, 2005, 2008 and 2009. Even though the data used is not constructed as a panel, according to documentation from INE and UDAPE, the greatest effort has been made to establish an acceptable level of similarity between the households in each different year of the surveys.

For each year, the household surveys are composed of 4260 households distributed across the country (except for the period 2003-04 where 4610 households were interviewed; the detail of the regions of households interviewed is available from the author upon request). The specifics on the data construction and sample distribution are explained in the accompanying documents to the surveys. ([28]-[31]). The variables presented in the surveys present the typical information for household level surveys. The selection of the years to be utilized was based on the availability of the surveys.

\section{ECONOMETRIC TECHNIQUE}

To assess the contribution to the reduction in poverty and inequality of several factors, I will use a regression-based decomposition technique, similar to the one developed by Fields [1]. This technique consists on regressing the expenditure of households against a vector of explanatory variables.

As explained by Fields [1] this approach allows to answer two questions. First, how much inequality in per capita expenditures can be accounted for by various household characteristics. Second, it enables to evaluate the impact of each characteristic.

The general regression is:

$$
\ln \left(Y_{i t}\right)=\alpha_{t}+\beta_{1 t} X_{i t}+\beta_{2 t} C T_{i t}+\varepsilon_{i t}
$$

where $i$ refers to each household, $t$ is year, $Y$ is the per capita expenditure for each household, and $X$ is a vector of explanatory variables composed of relevant household characteristics. To assess for the contribution of cash transfers, $C T$ is a variable that controls whether or not the household has received any cash transfer.

In this case, the variable $\mathrm{CT}_{1}$ will represent the reception of the cash transfers for the elderly, either the Bono Sol (for the years 2003/04 and 2005) or Renta Dignidad for the remaining years, $\mathrm{CT}_{2}$ will represent a transfer for families with new-born babies Bono de Natalidad, and $\mathrm{CT}_{3}$ will represent the reception of a transfer for primary school children Bono Juancito Pinto.

The vector $X$ can include several characteristics from the diverse set of variables presented in the household survey, in this specific research I have picked the following: a dummy variable to indicate if the household's head considers belonging to a specific ethnic group, a dummy variable for gender and dummy variables for educational attainment. Additionally, and to avoid spurious regression results, the variable age squared which represents the squared age of the household's head age is utilized.

\section{EMPIRICAL RESULTS}

The regression results for the model specified in Equation (1) are reported in Table 6. The empirical results presented, confirm the results made by other authors on the same issue (e.g. [2], [3]).

TABLE VI: REGRESSION RESULTS

Dependent variableis expenditure for each household

\begin{tabular}{lcccc} 
& $\mathbf{2 0 0 3 - 2 0 0 4}$ & $\mathbf{2 0 0 5}$ & $\mathbf{2 0 0 8}$ & $\mathbf{2 0 0 9}$ \\
Head of hh age & 0.0156 & 0.0113 & 0.0108 & 0.0139 \\
& $(6.42)$ & $(7.84)$ & $(6.94)$ & $(247)$ \\
Head of hh age squared & 0.0003 & 0.0113 & 0.0108 & 0.0139 \\
& $(0.00)$ & $(7.84)$ & $(6.94)$ & $(247)$ \\
Head of hh indigenous & -0.1472 & -0.1385 & -0.1486 & -0.1297 \\
& $(-4.78)$ & $(-4.52)$ & $(-4.04)$ & $(-3.94)$ \\
Head of hh fermale & -0.047 & -0.0475 & -0.0384 & -0.0594 \\
& $(-1.23)$ & $(-1.09)$ & $(-1.76)$ & $(1.65)$ \\
Head of hh primary & 0.4921 & 0.4725 & 0.4239 & 0.5192 \\
& $(3.68)$ & $(4.92)$ & $(5.01)$ & $(3.84)$ \\
Head of hh secondary & 0.8154 & 0.7845 & 0.7642 & 0.7264 \\
& $(7.01)$ & $(7.46)$ & $(6.41)$ & $(6.01)$ \\
Head of hh superior/tech educ & 1.7471 & 1.4278 & 1.5762 & 1.6414 \\
& $(14.08)$ & $(17.07)$ & $(15.85)$ & $(1624)$ \\
ReceiveCT1 & 0.0997 & 0.0112 & 0.0348 & 0.0647 \\
& $(1.97)$ & $(1.52)$ & $(1.99)$ & $(203)$ \\
ReceiveCT2 & 0.0098 & 0.0112 & 0.0348 & 0.0647 \\
& $(1.87)$ & $(1.52)$ & $(1.99)$ & $(203)$ \\
ReceiveCT3 & & 0.0112 & 0.0348 & 0.0647 \\
& & $(1.52)$ & $(1.99)$ & $(203)$ \\
C & 4.1786 & 4.1385 & 4.7895 & 4.8731 \\
& $(28.46)$ & $(30.85)$ & $(29.75)$ & $(27.86)$ \\
\hline n & 4610 & 4260 & 4260 & 4260 \\
R'2 & 0.3628 & 0.3264 & 0.3345 & 0.3479 \\
& Source: Own calculation & Note: $\mathrm{t}$ statistics are in parenthesis
\end{tabular}

In the long run, education and demographic change tend to explain the income inequality. In the results, the gender of the head of household does not present a statistical significance.

Regarding the specific contribution of cash transfers, it is important to note that the variable cash transfer does not enjoy statistical relevance in the year 2002, result that goes in line with Jemio [27]. The contribution in later years seems to increase; this fact could be attributed to the increment on the beneficiaries for the program Juancito Pinto (as stated before, the government of President Morales expanded the program in 2008).

Overall, education seems to be the main contributor to the success in the reduction of inequality in Bolivia, however the education sector, and especially educational achievement in Bolivia has been plagued by both supply and demand side constrains, Urquiola, 2000 [21] expands on this view.

An improvement on educational levels could lead to a reduction in poverty and inequality even further.

The effect of education here presented, could be also related to a declining ethnic gap in education. Traditionally Bolivia has suffered from extensive gaps in the supply of education between rural and urban areas and very strong differentiation of secondary and tertiary education between 
ethnic groups (several authors expand on this issue [3]). This is closely related to the rural to urban migration process that the country experiences. It is also important to assess the effect of quality of education when talking about the improvement in the poverty and inequality figures; sadly the present data does not provide enough information to control for this specific issue.

\section{CONCLUSION}

While the poverty-reducing effects should be analyzed in detail, the evidence presented here suggests that both Renta Dignidad and Juancito Pinto contribute in less scale than education to the reduction in poverty and inequality figures in Bolivia. The available evidence also suggests that it is too early to gauge the full effect of both social transfers over poverty and inequality in the long run. Unfortunately, neither transfer was preceded by a careful baseline survey.

The evidence also suggests a change in the trend with previous years regarding the modification -for good- of trends in poverty and inequality inside Bolivia. It seems that the improvement of education, more than any other policy has contributed to the declining figures of inequality.

The important issue however is to single out the policies that contribute to this improvement. This research sheds some light into the policies that are currently contributing to the reduction of poverty and inequality, however further research that accounts for broader temporal sets and redefined econometric techniques is necessary.

Future evaluation studies will require paired comparisons and econometric controls to measure the specific effect of transfers on poor and non-poor households. Over the long run, and from a comparative perspective, conditional cash transfers have been moderately successful in other countries in the region, when accompanied by adequate social service coverage.

It is also important to point out that the econometric technique utilized in the present research is basic regarding the link between CT programs, education and reduction of poverty and inequality. Despite the arguments that (Fields, 2003) states, it is arguable that the presented results here only provide information on the impact that CTs and education have on the expansion of wellbeing (through expenditure) at household level. The model is indirectly used to evaluate the contribution of transfers to the reduction of poverty and inequality; however it fails to establish a clear causality link. A model that empirically links the direct effect and -most importantly- the causality that cash transfers have on the reduction of poverty and inequality is yet to be applied for the specific case of Bolivia. Moreover, this study does not attempt to evaluate the cash transfer programs, since it does not assess for the specific objectives involved in the creation of the programs nor it utilizes proper modeling approaches to evaluate the programs. In the future, techniques of randomization such as the proposed by Ravallion [32], or others (e.g. [33]-[35]) should be implemented to properly evaluate the cash transfer programs.

\section{APPENDIX}

TABLE VII: MONTHLy EXPENDITURE PER PERSON POVERTy LINE 1996-2009 (IN BS. AND US\$)

\begin{tabular}{|c|c|c|c|c|c|c|c|}
\hline Bs. & 1996 & 1997 & 1998 & 1999 & 2000 & 2001 & 2002 \\
\hline Rural & 220.83 & 230.00 & 230.00 & 237.10 & 231.60 & 231.47 & 233.39 \\
\hline Uuban & 282.20 & 313.80 & 313.80 & 323.60 & 323.00 & 320.90 & 321.80 \\
\hline B. & 2003-2004 & 2005 & 2006 & 2007 & 2008 & 2009 & \\
\hline Rural & 270.53 & 281.52 & 294.00 & 360.05 & 456.73 & 423.79 & \\
\hline Unban & 331.70 & 358.50 & 383.60 & 463.40 & 590.40 & 605.60 & \\
\hline US\$ & 1996 & 1997 & 1998 & 1999 & 2000 & 2001 & 2002 \\
\hline Rural & 4255 & 4283 & 40.71 & 39.52 & 36.30 & 33.99 & 31.33 \\
\hline Uhben & 54.37 & 58.44 & 55.54 & 53.93 & 50.63 & 47.12 & 43.19 \\
\hline US\$ & 2003-2004 & 2005 & 2006 & 2007 & 2008 & 2009 & \\
\hline Rural & 34.11 & 34.84 & 37.07 & 47.56 & 64.60 & 59.94 & \\
\hline Unban & 41.83 & 44.37 & 48.37 & 61.22 & 83.51 & 85.66 & \\
\hline
\end{tabular}

Source: Adapted from Bolivia's Analysis Unit for Social and Economical Policies (Unidad de Anális de Políticas Sociales y Económicas, 2011)

TABLE VIII: MONTHLY EXPENDITURE PER PERSON INDIGENCE LINE 1996-2009 (IN BS. AND US\$)

\begin{tabular}{|c|c|c|c|c|c|c|c|}
\hline B. & 1996 & 1997 & 1998 & 1999 & 2000 & 2001 & 2002 \\
\hline Rural & 220.83 & 230.00 & 230.00 & 237.10 & 231.60 & 231.47 & 233.39 \\
\hline Utban & 282.20 & 313.80 & 313.80 & 323.60 & 323.00 & 320.90 & 321.80 \\
\hline B. & $2003-2004$ & 2005 & 2006 & 2007 & 2008 & 2009 & \\
\hline Rural & 270.53 & 281.52 & 294.00 & 360.05 & 456.73 & 423.79 & \\
\hline Utban & 331.70 & 358.50 & 383.60 & 463.40 & 590.40 & 605.60 & \\
\hline US\$ & 1996 & 1997 & 1998 & 1999 & 2000 & 2001 & 2002 \\
\hline Rural & 42.55 & 42.83 & 40.71 & 39.52 & 36.30 & 33.99 & 31.33 \\
\hline Utban & 54.37 & 58.44 & 55.54 & 53.93 & 50.63 & 47.12 & 43.19 \\
\hline US\$ & $2003-2004$ & 2005 & 2006 & 2007 & 2008 & 2009 & \\
\hline Rural & 34.11 & 34.84 & 37.07 & 47.56 & 64.60 & 59.94 & \\
\hline Uuban & 41.83 & 44.37 & 48.37 & 61.22 & 83.51 & 85.66 & \\
\hline
\end{tabular}

Source: Adapted from Bolivia's Analysis Unit for Social and Economical

Policies (Unidad de Análisis de Políticas Sociales y Económicas, 2011)

\section{REFERENCES}

[1] G. S. Fields, "Accounting for income inequality and its change: A new method, with application to the distribution of earnings in the United States," In Worker well-being and Public Policy (Research in Labor Economics) ed. S. W. Polachek, Elsevier Science, Amsterdam, pp. 1-38, 2003.

[2] G. Gray-Molina, W. Jiménez, E. Pérez de Rada, and E. Yáñez, "Poverty and assets in Bolivia: What role does social capital play?," in Portrait of the poor: An assets-based approach. O. Attanasio and M. Szekely, (eds), "Inter American Development Bank," Washington D.C., pp. 46-83, 2001

[3] G. Gray Molina and E. Yañez, "The Dynamics of Inequality in the Best and Worst Times: Bolivia 1997-2007," UNDP project "Markets, the State, and the Dynamics of Inequality: How to Advance Inclusive Growth," coordinated by L. Felipe López-Calva and N. Lustig. 2009

[4] K. Hoffman and M. A. Centeno, "The lopsided continent: inequality in Latin America," Annual Review of Sociology, vol.29, pp. 396-390 363-390, 2003.

[5] R. P. Korzeniewicz and W. C. Smith, "Poverty, inequality, and growth in Latin America: Searching for the high road to globalization," Latin American research review, vol. 35, no. 3, pp. 7-54, 2000.

[6] E. E. Leamer, H. Maul, S. Rodriguez, and P. K. Schott, "Does natural resource abundance increase Latin American income inequality?" Journal of Development Economics, vol. 59, pp. 3-42, 1999.

[7] J. L. Londoño and M. Székely, "Persistent poverty and excess inequality: Latin America, 1970-1995," Journal of Applied Economics, vol. 3, pp. 93-134, 2000

[8] M. Székely and M. Hilgert, "What's Behind the Inequality we Measure: An Investigation Using Latin American Data," IADB Working Papers, vol. 409, 1999.

[9] L. López Calva and N. Lustig, "Explaining the Decline in Inequality in Latin America: Technological Change, Educational Upgrading and Democracy," in Declining Inequality in Latin America: a decade of 
progress eds. L. López Calva \& N. Lustig Inter American Development Bank, Washington D.C., USA. pp. 1-24, 2010.

[10] F. H. G. Ferreira and M. Ravallion, "Global poverty and inequality: a review of the evidence," in WB Policy Research Working Paper Series, vol. 4623,2008

[11] N. Lustig and J. E. Taylor, Mexico: "The remaking of an economy," Journal of Economic Literature, vol. 32, pp. 134-134, 1994.

[12] A. Janvry and E. Sadoulet, "Growth, poverty, and inequality in Latin America: A causal analysis, 1970-94," Review of Income and Wealth, vol. 46, pp. 267-287, 2000 .

[13] K. M. Roberts, "Social inequalities without class cleavages in Latin America's neoliberal era," Studies in Comparative International Development (SCID), vol. 36, pp. 3-33, 2002.

[14] W. I. Robinson, "Latin America in the age of inequality: Confronting the new 'Utopia," International Studies Review, vol. 1, pp. 41-67, 1999.

[15] E. E. Telles, "Urban labor market segmentation and income in Brazil," Economic Development and Cultural Change, vol. 41, pp. 231-249. 1999.

[16] S. Burchfield, "A longitudinal study of the effect of integrated literacy and basic education programs on the participation of women in social and economic development in Bolivia," World Education Inc. Working Paper, Washington D.C., 2002.

[17] M. L. Faye, J. W. McArthur, J. D. Sachs, and T. Snow, "The challenges facing landlocked developing countries," in Journal of Human Development, vol. 5, pp. 31-68, 2004.

[18] C. Grootaert and D. Narayan, "Local institutions, poverty and household welfare in Bolivia," World Development, vol. 32 pp. 1179-1198, 2004.

[19] J. H. Merryman and E. D. Ackerman, "International law, development and the transit trade of landlocked states: The case of Bolivia," Metzner in Komm, 1969.

[20] G. Sandóval and J. Cordova, "Grassroots organizations and local development in Bolivia: A study of the municipalities of Tiahuanacu, Mizque, Villa Serrano, and Charagua," Local Level Institution. Working Paper No. 4 World Bank, Social Development Family, Environmentally and Socially Sustainable Development Network, vol.4, 1998.

[21] M. Urquiola, "Geography and development in Bolivia: migration, urban and inustrial concentration, welfare, and convergence: 1950-1992," Inter-American Development Bank, Washington D.C., 2000.

[22] E. Lora, "A decade of structural reforms in Latin America, what has been achieved and how to measure it" "Una década de reformas estructurales en América Latina: qué se ha reformado y cómo medirlo," Pensamiento iberoamericano, vol. 27, 1998.
[23] S. Klasen, M. Grosse, R. Thiele, J. Lay, J. Spatz, and M. Wiebelt, "Operationalizing Pro-Poor Growth-Country Case Study: Bolivia," Ibero America Institute for Econ. Research (IAI) Discussion Papers no. 101, Ibero America Institute for Econ. Research, 2004.

[24] S. Calvo, "Applying the Growth Diagnostics Approach: the Case of Bolivia," Bolivia-Country Economic Memorandum (Annex 2.1). World Bank Report \# 32233-BO. October 2005.

[25] D. Kaufmann, M. Mastruzzi, and D. Zavaleta, "Sustained Macroeconomic Reforms, Tepid Growth: A Governance Puzzle in Bolivia?" in In Search of Prosperity: Analytic Narratives on Economic Growth ed. D. Rodrik, Princeton University Press, NJ, 2003.

[26] Unidad de Análisis de Políticas Sociales y Económicas, "Dossier of social and economic statistics Bolivia," Dossier de estadísticas sociales y económicas de Bolivia. UDAPE La Paz, Bolivia, 2011

[27] L. C. Jemio, "Macro and Micro effects of BONOSOL" "Efectos Microy Macroeconómicos del BONOSOL," Fundación Milenio, La Paz, Bolivia 2006.

[28] Instituto Nacional de Estadistica Bolivia, Methodological Document, Household Continious Survey ECH-MECOVI 2003-04, Documento Metodologico Encuesta Continua de Hogares ECH-MECOVI 2003-04. La Paz: INE Bolivia, 2004.

[29] Instituto Nacional de Estadistica Bolivia, Methodological Document, Household Continious Survey ECH-MECOVI 2005, Documento Metodologico Encuesta Continua de Hogares ECH-MECOVI 2005. La Paz: INE Bolivia, 2006.

[30] Instituto Nacional de Estadistica Bolivia, Methodological Document, Household Continious Survey ECH-MECOVI 2008, Documento Metodologico Encuesta Continua de Hogares ECH-MECOVI 2008 La Paz: INE Bolivia, 2009.

[31] Instituto Nacional de Estadistica Bolivia, Methodological Document, Household Continious Survey ECH-MECOVI 2009, Documento Metodologico Encuesta Continua de Hogares ECH-MECOVI 2009. La Paz: INE Bolivia, 2010

[32] M. Ravallion, "The mystery of the vanishing benefits: An introduction to impact evaluation," The World Bank Economic Review, vol. 15 pp. 115-140, 2001

[33] J. Angrist, E. Bettinger, E. Bloom, E. King, and M. Kremer, "Vouchers for private schooling in Colombia: Evidence from a randomized natural experiment," in American Economic Review, vol. 92, no. 5, pp. 1535, 2002.

[34] J. D. Angrist and J. S. Pischke, Mostly harmless econometrics: An empiricist's companion, 1st ed. Princeton Univ Press, Princeton, NJ 2008.

[35] E. Duflo, R. Glennerster, and M. Kremer, "Using randomization in development economics research: A toolkit. Handbook of development economics," CEPR Discussion Papers no. 6059. CEPR Discussion Papers, 2007. 